\title{
INTRODUCTION: THE ETHICS OF LAWYERS IN GOVERNMENT*
}

\author{
MARGARET TARKINGTON
}

It is likely impossible to articulate or capture the importance of ethics in government. Corruption in government, or, as Vincent Blasi stated, "the abuse of official power" is, in fact, "an especially serious evil." Government officials can commandeer the police power of the state and the full weight of government power to their selfish ends if their abuse of that power is not checked.

Oddly enough, lawyers - both inside and outside of government service - provide a major role in checking the use and abuse of government power and official self-dealing. Lawyers inside government service have the opportunity to be gatekeepers for the rule of law and defenders of due process. The basic premise of due process is that government will not deprive people of life, liberty, and property without adherence to legal processes and substantive rights. Government lawyers are poised to uphold due process and constitutional governance - and thus arguably have a heightened duty to ensure that their client is acting justly and in accordance with law.

Attorneys outside of government service also play a major role in checking government power. Suits against federal, state, and local government and government officials are a crucial aspect of lawyering in the United States. The Supreme Court recognized in NAACP v. Button, "litigation . . is a means for achieving the lawful objectives of equality of treatment by all government, federal, state and local."'3 Attorneys perform a vast amount of checking government power: It happens in suits against local law enforcement, the President, and everyone in between - checking their use and abuse of government power. It occurs on behalf of citizens, noncitizens, immigrants, criminals, and even alleged terrorists. ${ }^{4}$

Today, on the national political stage, the ethics of government officials and

* On January 3, 2019, the AALS Professional Responsibility Section held its annual program on the topic, The Ethics of Lawyers in Government, in New Orleans, Louisiana. This article introduces and overviews the presentations made at that program. Professor Tarkington, who served as the Chair of the Professional Responsibility Section, moderated the program. Kathleen Clark presented the article which follows this introduction. The papers presented at the program by Rebecca Roiphe and Melissa Mortazavi were published in the Fordham Law Review. See generally Bruce A. Green \& Rebecca Roiphe, May Federal Prosecutors Take Direction from the President?, 47 Fordham L. REV. 1817 (2019); Melissa Mortazavi, Lawyer Independence in the Administrative State, 47 Fordham L. REv. 1937 (2019). Additionally, Professor Yaroshefsky unfortunately became ill and was unable to present her paper at the meeting. See generally Ellen Yaroshefsky, Regulation of Lawyers in Government beyond the Client Representation Role, 33 Notre Dame J.L Ethics \& Pub. Pol'y (forthcoming 2019).

2. Vincent Blasi, The Checking Value in First Amendment Theory, 2 AM. B. Found. RES. J. 521, 528, 538 .

3. NAACP v. Button, 371 U.S. 415, 429 (1963).

4. Margaret Tarkington, Voice of Justice: Reclaiming the First Amendment RiGHTS OF LAWYERS 60-62 (2018). 
their lawyers - as well as lawyers heading government agencies and investigations - are facing national scrutiny and attention. Our President publicly derided the investigations and work of Robert Mueller and his team - calling into question the legality and overall legitimacy of their activities. High ranking government attorneys-Jeff Sessions, Sally Yates, James Comey, Preet Bharara - have been removed from office. The President's personal lawyers, such as Michael Cohen and Rudy Guilliani, are national spectacles, constantly featured in high-profile press coverage. The press and citizenry on both sides of the political divide are engaged in a robust debate regarding the legitimacy and integrity of our government and its processes.

In this climate, what are the roles and obligations of lawyers in government service? What responsibilities do lawyers have - and what concrete actions can they take - if and when lawyers find themselves working for a government employer who is engaged in potentially unethical, unconstitutional, or illegal activity? What can and should lawyers do to preserve and improve the legitimacy and integrity of our system of government?

The panelists for this program, The Ethics of Lawyers in Government, include some of the foremost authorities on ethics in government and the role of government lawyers: Richard Painter, Kathleen Clark, Rebecca Roiphe, Melissa Mortazavi, and Ellen Yaroshefsky.

Richard Painter currently serves as the Vice Chair of the organization, Citizens for Responsibility and Ethics in Washington, and he previously served as the chief ethics lawyer to the U.S. President from 2005 to 2007 during the Bush administration. Professor Painter focused his discussion on curbing financial conflicts of interest in the legislature. He noted that in 1720, the English House of Commons passed the Bubble Act in response to insider trading and bribery by the legislature, but the act had little curbing effect. ${ }^{5}$ And early in the history of our country - in 1789-our First Congress approved Alexander Hamilton's plan to redeem Revolutionary War Bonds at full value. Prior to this becoming public knowledge, members of Congress bought up the bonds, which were trading at thirty to forty cents on the dollar, precisely so they could then redeem them at full value once that value was guaranteed by law. ${ }^{6}$

Painter noted that some financial conflicts of interest of government officials were not recognized early on, yet the Framers did recognize that if foreign governments could buy off or otherwise financially influence US government officials, that would present very serious problems. Consequently, the Framers included in the Constitution the Emoluments Clause - which to this day serves as a constitutional "anti-corruption principle," as Painter called it. That clause states that "no Person holding any Office of Profit or Trust under [the United

5. See, e.g., Richard W. Painter, Ethics and Corruption in Business and Government: Lessons from the South Sea Bubble and the Bank of the United States (2006) (Minnesota Legal Studies Research Paper No. 06-32, 2006), available at http://ssrn.com/abstract=920912.

6. See Donna M. Nagy \& Richard W. Painter, Selective Disclosure by Federal Officials and the Case for an FGD (Fairer Government Disclosure) Regime, 2012 WIS. L. REV. 1285, 1296-97 and nn.48-50. 
States], shall, without the Consent of the Congress, accept of any present, Emolument, Office, or Title, of any kind whatever, from any King, Prince, or foreign State."

Similarly, Painter pointed out that 18 U.S.C. $\S 208$ makes it a crime for officers of the executive branch to engage in official actions that serve the officer's own financial interests or those of close relatives. Nevertheless, members of Congress can hold millions of dollars of stock in pharmaceutical companies and vote on health care legislation that will affect the value of that stock. They can hold stock in fossil fuels and then vote to defeat environmental legislation that will financially harm their holdings. Painter opined that Congress cannot effectively challenge the President regarding his financial conflicts of interest if Congress is not held to abide by the same principles.

As to government lawyers, Painter maintained that government lawyers have an ethical obligation to go beyond advising compliance with a minimal interpretation of the letter of the law, but to consider both the law's letter and its spirit. Government lawyers should not go along with government actors when a course of action is one that technically is permissible under the law, but which undermines the actual purpose of the law. Instead, government lawyers have an obligation to encourage government officials to act with integrity in upholding laws, rather than trying to get away with technical compliance while eviscerating public interest purposes underlying those laws.

Kathleen Clark, whose intriguing article follows this introduction, discussed how the Department of Justice (DOJ), in interpreting the Emoluments Clause with respect to President Trump, has mis-identified its actual client. Clark noted that the Emoluments Clause had historically been broadly interpreted by the DOJ to forbid compensation, travel expenses, or even permission to perform research in foreign laboratories. In 1993, the DOJ interpreted the Emoluments Clause to forbid law firm partnership distributions if they flowed from foreign government matters.

As Clark recounted, prior to the current administration, the DOJ consistently preserved the anti-corruption concern underlying the Emoluments Clause, which enjoyed 150 years of robust protection and interpretation. Yet, after President Trump was sued for violating the clause, the current DOJ undermined its prior interpretations, instead adopting an alternative narrow interpretation of the Emoluments Clause that was proffered by President Trump's personal lawyers. Clark contended that, in so doing, the DOJ abandoned its actual client. The DOJ mistook President Trump as its client, rather than the government. This misidentification of client implicates Model Rule of Professional Conduct 1.13, which is the rule governing lawyers who represent entities, including governmental entities. ${ }^{8}$ The DOJ's client is the United States government, not the

7. U.S. Const. art. I, $\S 9$ (emphasis added).

8. See generally Model Rules Prof'L Conduct r. 1.13 and cmt. 9 (Am. BAR Ass'N 1993).

Model Rule 1.13 adopts an entity-theory of organizational representation. Thus, lawyers for an organization, including a government organization, represent the entity itself and owe their duties 
President. Clark opined that the President has the authority to direct the work of the DOJ as to overall policy, yet where there is a conflict of interest between institutional interests and the personal interests of the President, the President should not be directing the DOJ. When the interests of the government of the people diverge with the personal or financial interests of an individual officer, the government lawyer must protect the interests of his or her actual client, the government.

Rebecca Roiphe discussed a topic closely related to the issue of identifying the government lawyer's client. Presenting a paper written by herself and Bruce Green, May Federal Prosecutors Take Direction from the President?, which will be published in the Fordham Law Review, Roiphe discussed the consequences of interpreting the President's power as providing control over federal prosecutors and their discretionary decision-making. Roiphe referenced a letter, written by President Trump's lawyers to Robert Mueller, in which they asserted that the President has "exclusive authority over the ultimate conduct and disposition of all criminal investigations and over those executive branch officials responsible for conducting those investigations." " Roiphe argued that if the President had the power to direct and control federal prosecutors' discretion, he could effectively force prosecutors to violate their ethical obligations or to resign-neither of which is desirable. Moreover, Roiphe argued that separation of powers concerns would arise if the President ordered a prosecutor to take some action, but the relevant rules of professional conduct indicated that such action was inappropriate. Under the McDade Amendment, federal prosecutors are subject to the lawyer regulations of the state in which the attorney is practicing. ${ }^{10}$ Thus, Congress has subjected federal prosecutors to the state regulation of attorneys, which is governed and overseen by the judiciary. The judiciary has maintained primary authority over regulation of lawyers, and it would undermine the judiciary's power and role in governing lawyers - and Congressional direction in the McDade Amendment - if the President could direct prosecutors in ways contrary to, or in disregard of, state rules of professional conduct. Further, such presidential control would undermine lawyer independence, and thereby harm the integrity of the judiciary and the justice system, which depend upon lawyer independence and upon compliance with professional regulations and norms.

Melissa Mortazavi discussed the importance of lawyer independence in the administrative state. Mortazavi argued that lawyers, generally, need enough independence to examine "what the law is" free from undue coercion (although noting that there is always some coercion, as lawyers are paid). Lawyers must be able to determine whether their clients' goals are legal, and whether the means by

to the organization, and not to any of the individual constitutes, officers, or managers of the organization. See John P. SAhl et AL., Professional Responsibility in Focus 121-22, 139-40 (2017).

9. Letter from Marc E. Kasowitz, Counsel to the President, to Robert S. Mueller, Special Counsel (June 23, 2017), available at https://www.nytimes.com/interactive/2018/06/02/us/politics/ trump-legal-documents.html [https://perma.cc/A3WZ-56Y5].

10. See 28 U.S.C. $§ 530 B(a)(2019)$. 
which those goals are pursued are legal. Mortazavi argued that while this need for independence exists for all lawyering, it is critically essential for government lawyers because a legitimate government must be bound by norms of legality. This concern is arguably heightened for lawyers in the administrative state, where the judiciary performs less of a checking function than in other contexts because of the deferential review given to administrative agencies. Thus, lawyers working for administrative agencies perform a vital function as gatekeepers for the rule of law. Mortazavi recommended ways to protect lawyer independence in the administrative state, including workplace environment and culture. She noted that the DOJ and FBI have significant cultures of independence from political pressures, but other agencies lack such cultures. She offered suggestions for supporting a lawyer-specific culture across agencies, so that lawyers working in the administrative state could identify themselves with their kinship in the profession, rather than their agencies' political missions or the political party currently in power - and thus be committed to preserve their professional independence against political pressure.

One of the overarching themes that recurred throughout this program was the idea that the government lawyer plays a crucial role as a gatekeeper for upholding the rule of law. If government lawyers - those who advise government actors about the legality of their actions, those who work for government agencies, those who exercise prosecutorial power, and those who administer the law-fail to act as gatekeepers of the law, the law and its purposes can and will be undermined. Further, such a failure is particularly serious because it makes way for government unlawfulness and corruption. The failure of a government to uphold and abide by its own laws erodes its integrity and legitimacy. Unlawful actions by government actors are posed to cause unique and egregious harms as the full weight of government power can be imposed unfairly against people. Where government lawyers should be defenders of due process and the rule of law, they can instead become instruments of state oppression when they countenance, advise, or assist in unlawful and unethical actions of government officers or agencies.

Government lawyers fail to uphold their ethical and professional obligations when they mis-identify their client as individual politicians and work to fulfill the whims and designs of such individuals. ${ }^{11}$ They must instead maintain their professional independence, adhere to professional ethics, and recognize that they ultimately work for " $a$ sovereignty whose obligation to govern impartially is as compelling as its obligation to govern at all; and whose interest, therefore, ... [is] that justice shall be done." 12

11. This is certainly true of the government lawyers discussed in this program — prosecutors and those who advise or work for agencies, the legislature, or the President. However, some government lawyers, such as public defenders, should in fact treat their individual clients as their client — but even these lawyers are obligated to work within and uphold the rule of law.

12. Berger v. United States, 295 U.S. 78, 88 (1935) (emphasis added). 